\title{
Numerical Analysis of Active Earth Pressures on Various Types of Retaining Walls
}

\author{
Hakan Alper KAMİLOĞLU ${ }^{*}$ (D) Erol ŞADOĞLU² ${ }^{2}$ Fatih YILMAZ ${ }^{3}$ \\ ${ }^{1}$ Bayburt University Civil Engineering Department, Bayburt, Turkey \\ ${ }^{2}$ Karadeniz Technical University Civil Engineering Department, Trabzon, Turkey \\ ${ }^{1}$ Bayburt University Civil Engineering Department, Bayburt, Turkey
}

Geliş / Received: 21.11.2019, Kabul / Accepted: 19.12.2019

\begin{abstract}
Lateral earth pressure distribution is crucial in retaining structure design. In most studies, active earth pressure distribution acting on the retaining structure is supposed as nonlinear. Despite there are many studies about earth pressure distribution, there are limited number of studies considering effect of wall geometry on lateral earth pressure distribution. In this study, it is aimed to examine effect of wall geometry on active failure surfaces and lateral earth pressure distribution. Thus, active failure surface and active lateral earth pressure distribution of various types of retaining wall were examined numerically. Within scope of the analysis a gravity retaining wall with various inclinations, inverted $\mathrm{T}$ type cantilever retaining wall and gravity wall with various heel lengths were considered. The effect of wall inclination and heel length on failure mechanism and lateral earth pressure distribution was studied. As a result of the study it is shown that lateral earth pressure distribution varies based on wall type. Additionally, short heel and long heel cases are effective on earth pressure distribution.
\end{abstract}

Keywords: failure surface, lateral earth pressure distribution, long heel, short heel

\section{Farklı İstinat Duvar Tiplerinde Aktif Toprak Basınçlarının Sayısal Analizi}

\section{$\ddot{O} z$}

Dayanma yapılarının tasarımında yatay toprak basıncı dağılımı önem arz etmektedir. Birçok çalışmada, dayanma yapısına etkiyen aktif toprak basınç dağılımı nonlineer olarak kabul edilir. Toprak basınç dağılışı ile ilgili çok sayıda çalışma olmasına karşın, Duvar boyutlarının yatay toprak basıncı dağılışı üzerine etkilerini irdeleyen az sayıda çalışma bulunmaktadır. Bu çalışmada, duvar şeklinin aktif yanal toprak basınç dağılımı ve aktif kırılma yüzeyleri üzerine etkisi incelenmiştir. Bu nedenle çeşitli tip dayanma duvarlarına gelen yanal toprak basınç dağılışları ve oluşturdukları kırılma yüzeyleri numerik olarak irdelenmiştir. Yapılan çalışma kapsamında, çeşitli eğimlerdeki ağırlık tipi dayanma duvarları, farklı topuk uzunlukları ve eğime sahip ters T biçimli dayanma duvarları göz önüne alınmıştır. Yapılan çalışma sonucunda yanal toprak basınç dağılışının duvar tipine göre değiştiği belirlenmiştir. Buna ek olarak duvar eğimi ve topuk uzunluğunun kırılma yüzeyleri ve yanal toprak basınç dağılışı üzerinde etkili olduğu görülmüştür.

Anahtar Kelimeler: kırılma yüzeyi yatay toprak basınç dağılışı, uzun topuk, kısa topuk 


\section{Introduction}

Lateral earth pressure distribution plays vital role in retaining wall design. Beside widely known theories like Rankine (1857) and Coulomb (1776) there are various study considering different methods for lateral earth pressure distribution. Some of which are limit equilibrium method (Greco, 2013; Leśniewska \& Mróz, 2000; Morisson \& Ebeling, 1995), limit analysis method (Chen \& Liu, 1990; Shiau, Augarde, Lyamin, \& Sloan, 2009; Yang, 2007), numerical methods (Chugh \& Labuz, 2011; Lee, Chae, Kim, Jo, \& Park, 2015) and experimental methods (Chevalier, Combe, \& Villard, n.d.; Tsagareli, 1965). Contrary to the Coulomb's and Rankine's methods, in many studies it is stated that active earth pressure distribution is nonlinear due to the arching effect (Ertuğrul, 2013; Handy, 1985; Nadukuru \& Michalowski, 2012). Arching effect is clearly explained by Terzaghi (1943) with widely known trapdoor experiment. With reference to the experiment it is seen that failure surfaces play decisive role on lateral earth pressure distribution acting on a retaining structures.

Gravity (Dewaikar, Pandey, \& Dixit, 2012; V. Greco, 2013; Le, Wu, \& He, 2010), semigravity (Kamiloğlu, Şadoğlu, \& Yılmaz, 2019), cantilever or inverted T type retaining walls (Goh, 1993; Kamiloğlu \& Şadoğlu, 2019; Wall., 2012) are taken into account in the studies about determination of lateral earth pressure or lateral earth thrust. In the studies effect of different parameters such as wall inclination, heel length, foundation thickness, backfill inclination, density, surcharge on lateral earth pressure or lateral earth thrust were examined.

Heel has effective role on active failure mechanism (V. Greco, 2013). Retaining walls can be termed as short heel or long heel based on heel length and active failure surfaces occurring behind the wall. Kamiloğlu and Şadoğlu (2019) stated that active failure mechanisms occurring behind the wall with long heel and short heel are totally different.

Despite there are many studies considering earth pressure distribution, there are limited number of studies considering effect of heel length and wall inclination on lateral earth pressure distribution. Also, gravity retaining walls have mostly been considered in experimental or numerical studies about lateral earth pressure distribution. On the other hand, there are very few studies considering effects of wall inclination and heel lengths on active failure mechanism and lateral earth pressure distribution.

In this study, it is aimed to examine effect of wall geometry on active failure surfaces and lateral earth pressure distribution. Within this scope active case is considered. Failure mechanism and lateral earth pressure distribution of a semi-gravity wall, gravity walls with different inclinations and heel lengths, inverted $\mathrm{T}$ type cantilever retaining walls with various heel lengths were examined numerically. The analyses were performed using 2D Plaxsis 8.6. In the numerical analyses, the backfill was supposed to be a granular material and plane-strain condition was valid.

\section{Material and Methods}

\subsection{Numerical model}

Numerical analyses were performed using Plaxis 2D 8.6 commercially available finite element software. Features used in the FE analyses are shown in Table 1. In numerical model gravity retaining wall (Figure 1a), 
inclined gravity wall (Figure 1b), inverted T type retaining walls (Figure 1c) and inclinedinverted T type retaining wall (Figure 1d) with $3 \mathrm{~m}$ height were considered. The heel lengths (b) used in the analyses are $0 \mathrm{~m}, 0.3 \mathrm{~m}, 0.9 \mathrm{~m}$, $1.5 \mathrm{~m}$ and wall inclination angles are $0^{\circ}, 5^{\circ}$, $15^{\circ}, 20^{\circ}$.

In order to prevent intersection between the active failure surface and the vertical boundaries, horizontal and vertical dimensions of the model were chosen as $6 \mathrm{~m}$ (horizontal length is used as $8 \mathrm{~m}$ for some cantilever retaining walls) and $6 \mathrm{~m}$ respectively. Displacements of the vertical boundaries of the model were constrained in horizontal directions and the bottom boundary of the model was constrained horizontally and vertically. The retaining wall was translated horizontally away from the backfill to create active state. For each case it is supposed that the wall is translated enough to create active state $(0.001 * \mathrm{H})$.

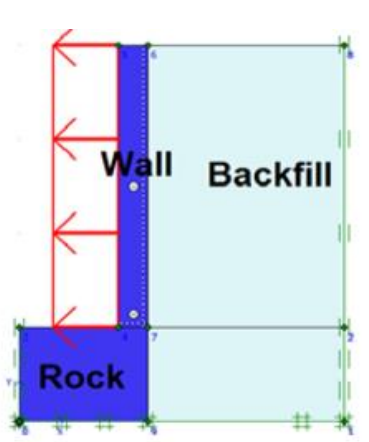

(a)

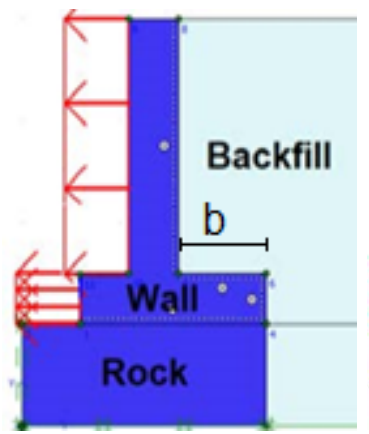

(c)

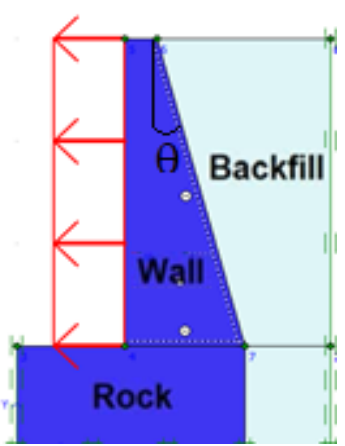

(b)

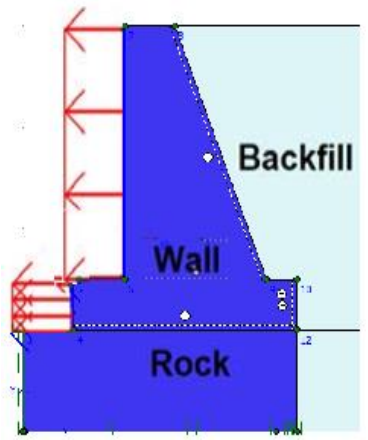

(d)

Figure 1. Typical geometry of retaining walls (a) Gravity wall (b) Inverted T type cantilever wall (c) Inclined gravity wall (d) Inclined inverted $\mathrm{T}$ type cantilever wall

Linear elastic material model (for retaining wall), Mohr-Coulomb material model (for the backfill) and six noded triangular element with three Gauss point were used in numerical analyses. In contact surfaces (wall-backfill,

Table 1. Parameters considered in the FE analyses

\begin{tabular}{lccc}
\hline PARAMETERS & BACKFILL & ROCK & WALL \\
\hline Material Model & Mohr-Coulomb & Linear Elastic & Linear Elastic \\
\hline Unit Weight, $\gamma$ & $15.4 \mathrm{kN} / \mathrm{m}^{3}$ & $24 \mathrm{kN} / \mathrm{m}^{3}$ & $24 \mathrm{kN} / \mathrm{m}^{3}$ \\
\hline Friction Angle, $\phi$ & $37^{\circ}$ & - & - \\
\hline Modulus of Elasticity, E & $50 \mathrm{MPa}$ & $20000 \mathrm{MPa}$ & $20000 \mathrm{MPa}$ \\
\hline Poisson's Ratio, $v$ & 0.3 & 0.2 & 0.2 \\
\hline Dilatancy Angle, $\psi$ & $7^{\circ}$ & - & - \\
\hline Interface Friction Angle (wall-backfill), $\delta$ & $17^{\circ}$ & - & - \\
\hline Rinter (wall-backfill) & 0.46 & - & - \\
\hline Interface Friction Angle (rock-backfill), $\delta$ & $0^{\circ}$ & - & - \\
\hline$R_{\text {inter }}$ (rock-backfill) & 0.01 & - & - \\
\hline
\end{tabular}


wall base-rock), interface elements were used to simulate the contact behavior. Strength reduction factors of the interface elements are determined as $\delta / \varphi$ value.

In order to determine ideal mesh size various FE analyses were performed considering different mesh dimensions. As a result of the $\mathrm{FE}$ analyses active failure surface mechanism and lateral earth pressure distributions were compared with other studies. The active failure mechanism occurring behind a gravity retaining wall obtained from the $\mathrm{FE}$ analysis (Figure 2a) was compared with experimental study performed by Cinicioglu et al.(2015) (Figure 2b) . The finest mesh size that gives the compatible failure surface mechanism with the numerical model was determined. The finite element mesh consists of 6857 elements and average element size of the model is $59.16 \times 10^{-3} \mathrm{~m}$. The mesh size of the element is refined locally around backfill and the wall, particularly near the contact surfaces between the wall and backfill.

The lateral earth pressure distribution was obtained considering the determined mesh size (Figure 2c). As it is seen from the figure, lateral earth pressure distribution is not smooth. Normalized depth-normalized lateral earth pressure graph is drawn and ideal curve is fitted. In this way, the smooth curve is obtained (Figure 2d)

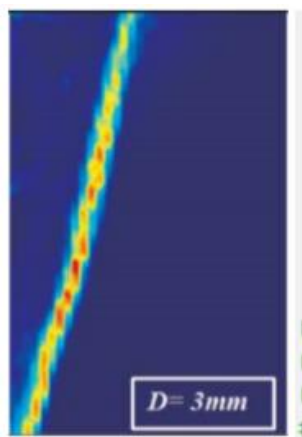

(a)

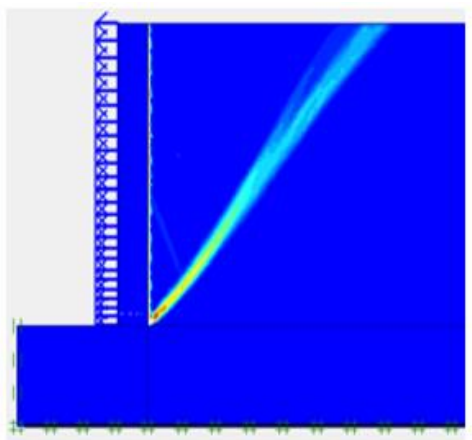

(b)

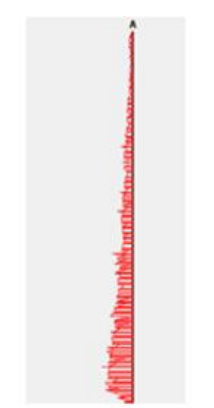

(c)

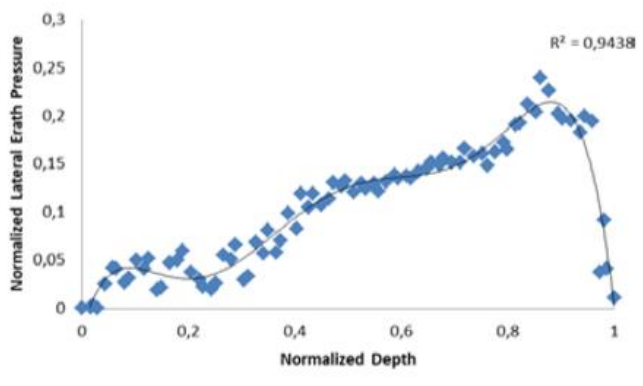

(d)
Figure 2. Failure mechanism and earth pressure distribution (a) Experimental results of active failure surface behind a gravity retaining wall Cinicioglu et al. (2015) (b) Failure surface mechanism obtained with the FE analysis. (c) Lateral earth pressure distribution for gravity retaining wall (d) Normalized lateral earth pressure-depth relation of gravity retaining wall. (Kamiloglu et al. 2019)

\subsection{Validation}

Lateral earth pressure distribution determined with FE analyses compared with experimental (Fang \& Ishibashi, 1986; Tsagareli, 1965) and analytical studies (Handy, 1985; Paik \& Salgado, 2003; Wang, 2000). The normalized pressure $\left(\sigma_{\text {horizontal }} / \gamma \mathrm{H}\right)$ and normalized depth $(\mathrm{z} / \mathrm{H})$ are considered for verification in order to compare various wall dimensions and wall inclinations. Calculated lateral earth pressure distribution is compared with field test result of (Tsagareli, 1965) and physical test data suggested by (Fang \& Ishibashi, 1986) in Figure $3 a$. In Figure $3 b$, the results are compared with results of numerical studies (Handy, 1985; Paik \& Salgado, 2003; Wang, 2000). It is seen from the Figures that there is good agreement between results of the finite element analyses and the experimental and numerical studies. 


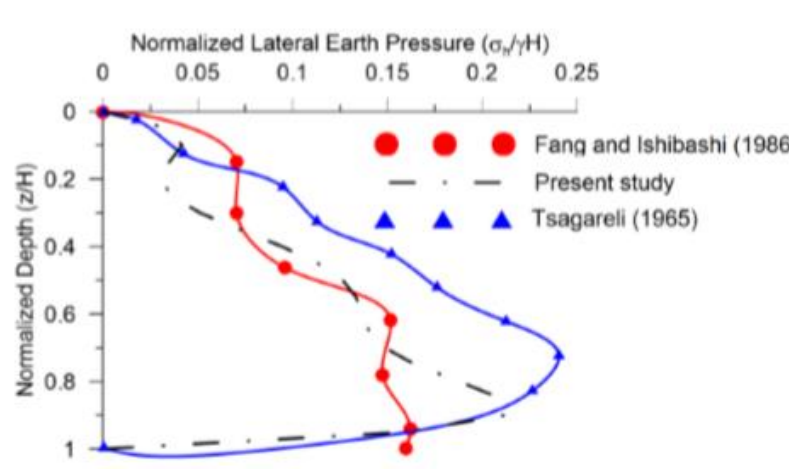

(a)

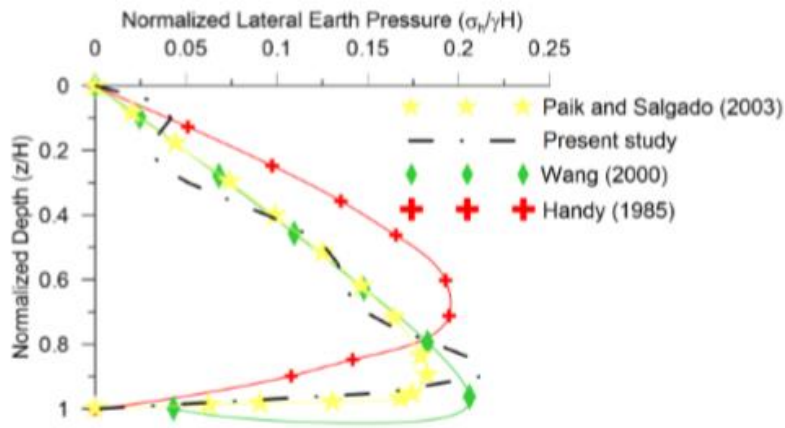

(b)

Figure 3. Comparison FEM results (a) with experimental data (b) with other numerical studies (Kamiloglu et al. 2019)

\subsection{Determination of Strain Fields Based on Retaining Wall Geometry}

In this part of the study active failure mechanism behind laterally translated walls are examined. As a result of the FE analyses determined active failure mechanism behind a gravity retaining wall with different inclinations $\left(0^{\circ}, 5^{\circ}, 10^{\circ}, 15^{\circ}, 20^{\circ}\right)$ is shown in Figure 4. From the figures it is seen that the contact surfaces increase with increasing wall inclination.

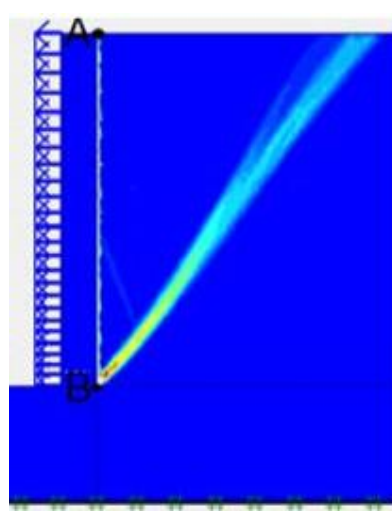

(a)

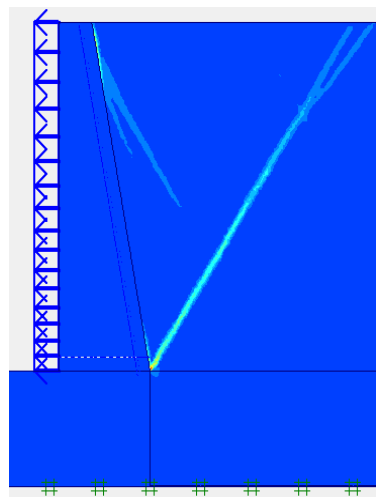

(c)

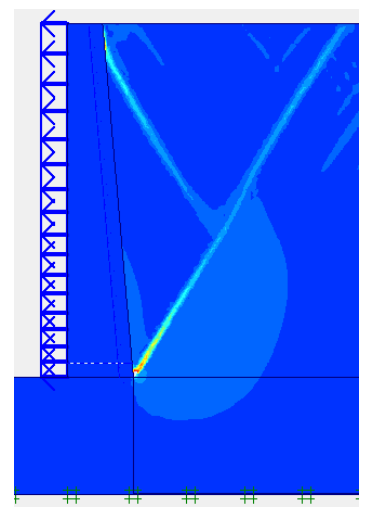

(b)

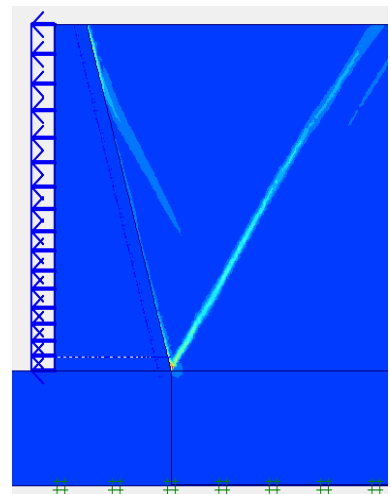

(d)

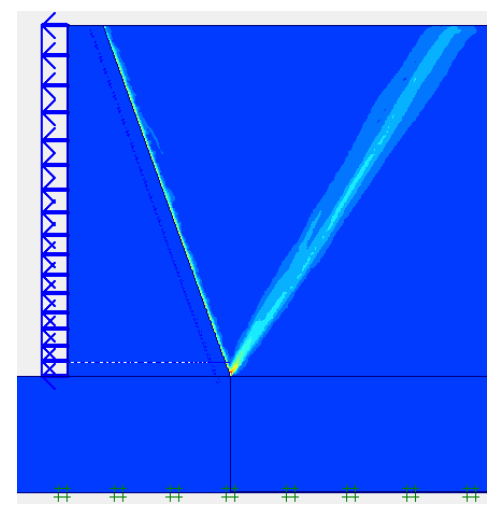

(e)

Figure 4. Active failure mechanism behind gravity wall with different inclinations (a) $\theta=0^{\circ}$ (Kamiloglu et al. 2019) (b) $\theta=5^{\circ}$ (c) $\theta=10^{\circ}$ (d) $\theta=15^{\circ}$ (e) $\theta=20^{\circ}$

Within scope of this study relation between heel length and active failure surface occurring behind inverted $\mathrm{T}$ type cantilever retaining wall is examined. Presented in Figure 5 are active failure mechanisms of the wall with various heel lengths $(b=0 \mathrm{~m}, 0.3 \mathrm{~m}$, $0.9 \mathrm{~m}, 1.5 \mathrm{~m}$ ). From the figures (Figure $5 \mathrm{~b}-5 \mathrm{~d}$ ) 
it is seen that active failure mechanism obtained with FE analyses are compatible with Kamiloglu and Sadoglu (2019)

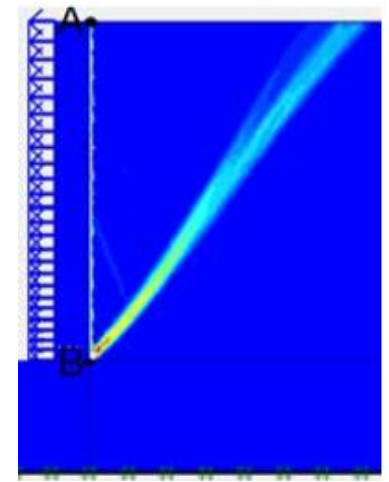

(a)

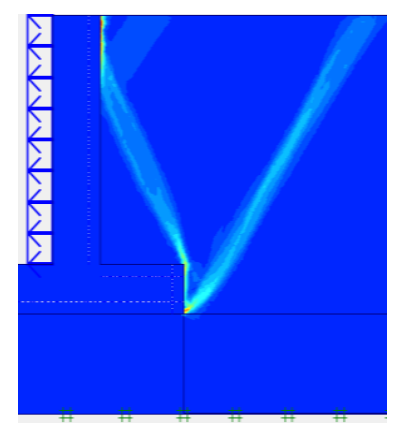

(c)

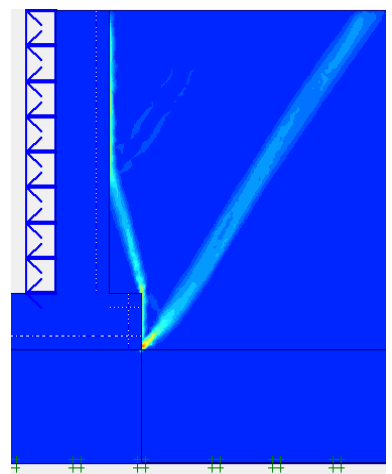

(b)

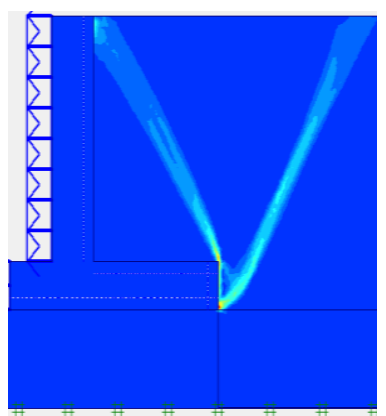

(d)
Figure 5. Active failure mechanism occurring behind inverted $\mathrm{T}$ type retaining wall with different heel lengths (a) $b=0 \mathrm{~m}$ (Kamiloglu et al. 2019) (b) $b=0.3 \mathrm{~m}$ (Kamiloglu et al. 2019) (c) $b=0.9 \mathrm{~m}$ (Kamiloglu et al. 2019) (d) $b=1.5$ m (Kamiloglu et al. 2019)

In this part of the study inclination of inverted $\mathrm{T}$ type cantilever wall is examined. Within this scope the wall with $0.3 \mathrm{~m}$ heel and $1.5 \mathrm{~m}$ heel is taken into account. In the analysis wall inclination angles are supposed as $10^{\circ}$ and $20^{\circ}$. Active failure mechanisms of inclined inverted $\mathrm{T}$ type cantilever walls are presented in Figure 6. By viewing the figures it is seen that wall inclination has effects on length of the contact surface for the walls with short heel.

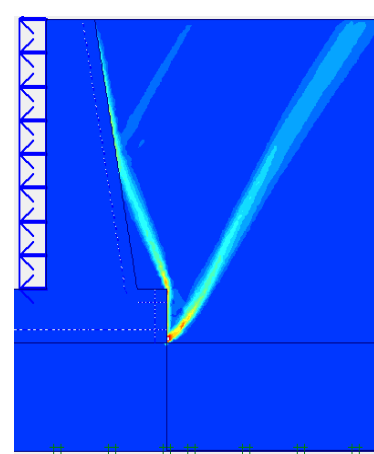

(a)

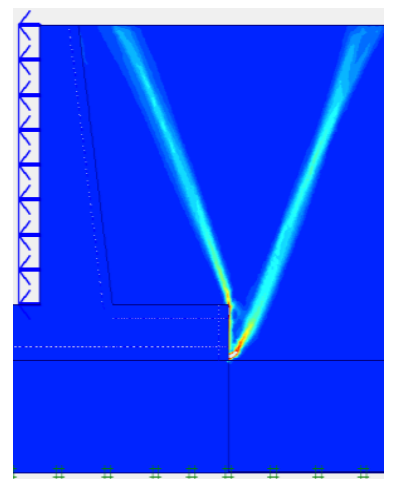

(c)

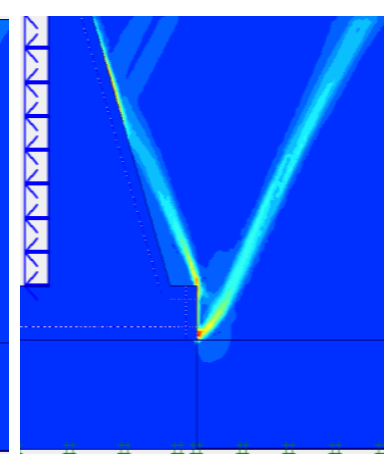

(b)

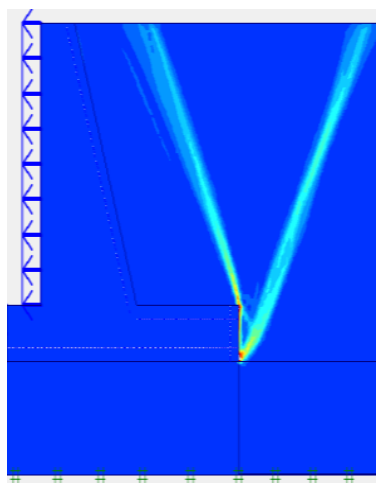

(d)
Figure 6. Active failure mechanism occurring behind inverted $\mathrm{T}$ type retaining wall with different heel lengths and inclinations (a) $\mathrm{b}=0.3 \mathrm{~m}, \theta=10^{\circ}$ (b) $\mathrm{b}=0.3 \mathrm{~m}, \theta=20^{\circ}$ (c) $\mathrm{b}=1.5$ $\mathrm{m}, \theta=10^{\circ}$ (d) $\mathrm{b}=1.5 \mathrm{~m}, \theta=20^{\circ}$

From the figures it is seen that strain fields change based on wall type and wall dimensions. The gravity retaining wall has the largest contact surface (Figure 4) and the contact surfaces between the inverted $\mathrm{T}$ type retaining wall and backfill (line $\mathrm{AB}$ ) decrease with increased heel length. Differently from the gravity retaining wall, the contact surfaces occur on the stem (line AB) and the foundation of the $\mathrm{T}$ type cantilever retaining walls.

\subsection{Determination of Lateral Earth Pressure Distribution}

The active lateral earth pressure distribution acting on stem and foundation of the gravity retaining walls are shown in Figure 7 . The 
stem of the gravity retaining wall was considered in the FE analyses. Effect of inclination of the gravity walls on lateral earth pressure distribution is shown in Figure 7.

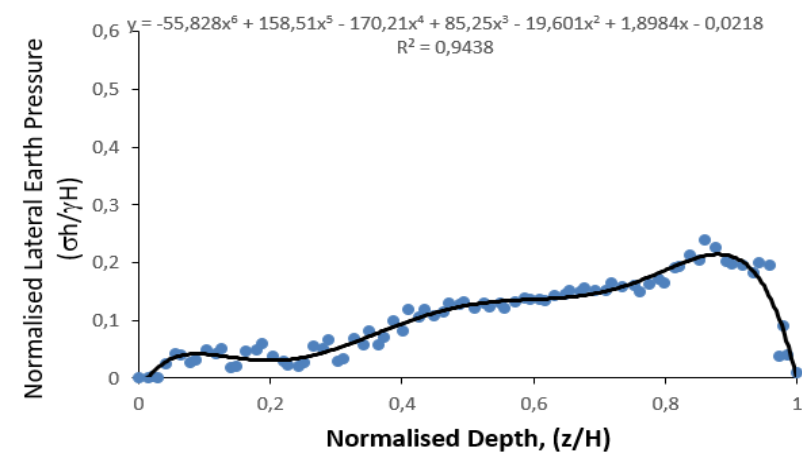

(a)

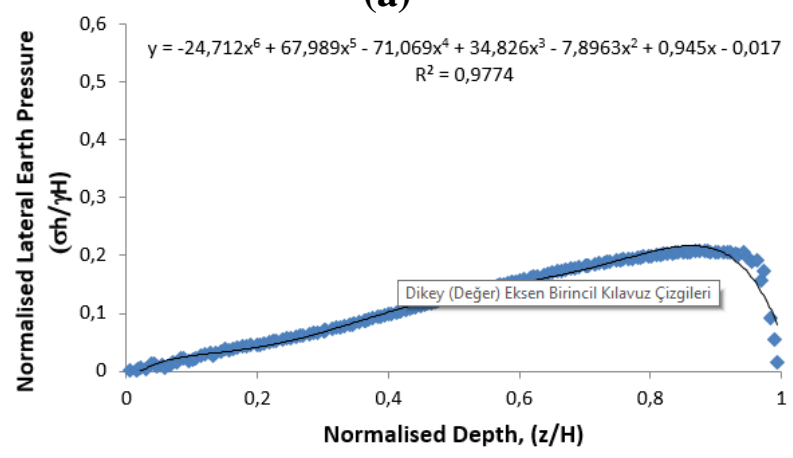

(b)

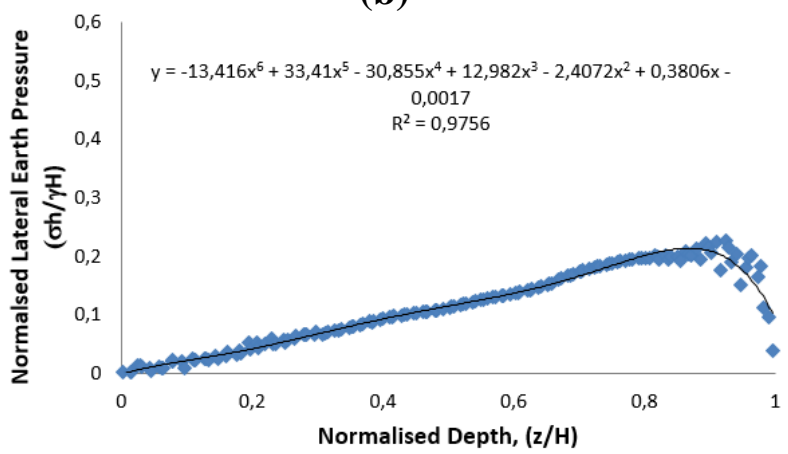

(c)

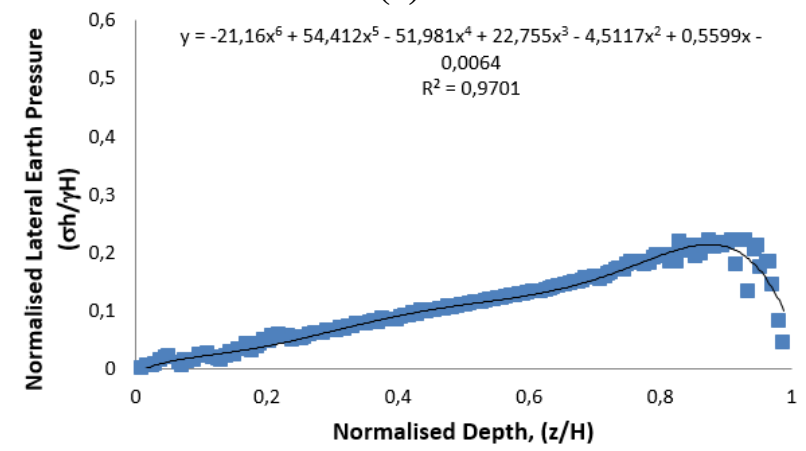

(d)

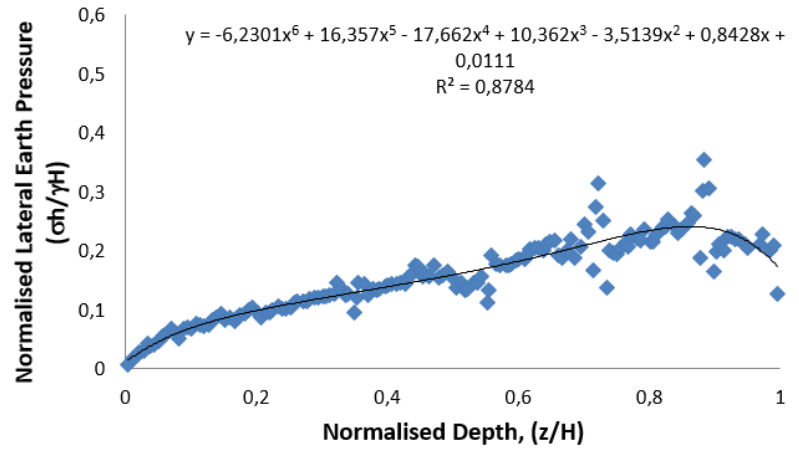

(e)

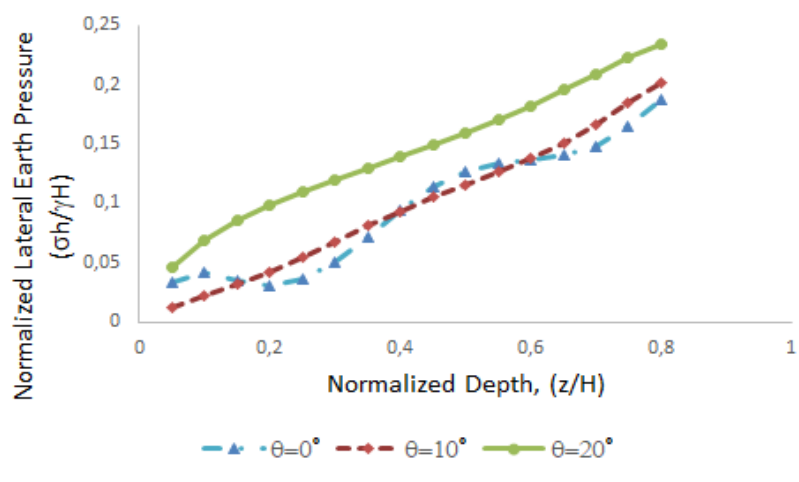

(f)

Figure 7. Active earth pressure distribution acting on the gravity retaining wall with different inclinations (a) $\theta=0^{\circ}$ (Kamiloglu et al. 2019) (b) $\theta=5^{\circ}$ (c) $\theta=10^{\circ}$ (d) $\theta=15^{\circ}$ (e) $\theta=20^{\circ}$ (f) Lateral earth pressure distribution acting on the gravity walls with various inclination

The stem and the foundation were considered separately for the inverted $\mathrm{T}$ type cantilever retaining walls (Figure 8-9). In order to ensure comparableness, the stem height of the $\mathrm{T}$ type retaining wall was taken into account. Thus, lateral earth pressure acting on $0-2.5 \mathrm{~m}$ of the gravity retaining wall was considered.

In the FE analyses foundation thickness and the stem height of the $\mathrm{T}$ type retaining wall is supposed as $0.5 \mathrm{~m}$ and $2.5 \mathrm{~m}$ respectively. The normalized height of the stem varies between $0-0.833$ and the normalized height of the foundation changes between 0.833-1. As the stem height of the gravity retaining wall is considered as $3 \mathrm{~m}$, normalized depth varies 
between 0 and 1. Lateral earth pressure distribution curve of inverted $\mathrm{T}$ type retaining wall shown in Figure 8 and 9 consists of two parts. The first part of the curve shows lateral earth pressure distribution between $\mathrm{z} / \mathrm{H}=0$ and $\mathrm{z} / \mathrm{H}=0.833$. The second part of the curve represents the pressure distribution between $\mathrm{z} / \mathrm{H}=0.833$ and $\mathrm{z} / \mathrm{H}=1$. In the figures the pressure distributions acting on the stem $(\mathrm{z} / \mathrm{H}=0-0.833)$ and foundation $(\mathrm{z} / \mathrm{H}=0.833-1)$ are shown separately. The normalized lateral earth pressure $\left(\sigma_{\mathrm{h}} / \gamma \mathrm{H}\right)$ distribution acting on the stem of inverted $\mathrm{T}$ type retaining walls and heel length are compared in Figure 8. After examining Figure 7 and Figure 8 it is seen that scatter pressure distribution obtained from the contact surfaces. On the other hand, smooth lateral earth pressure curves are observed from the wall where strain fields do not occur.

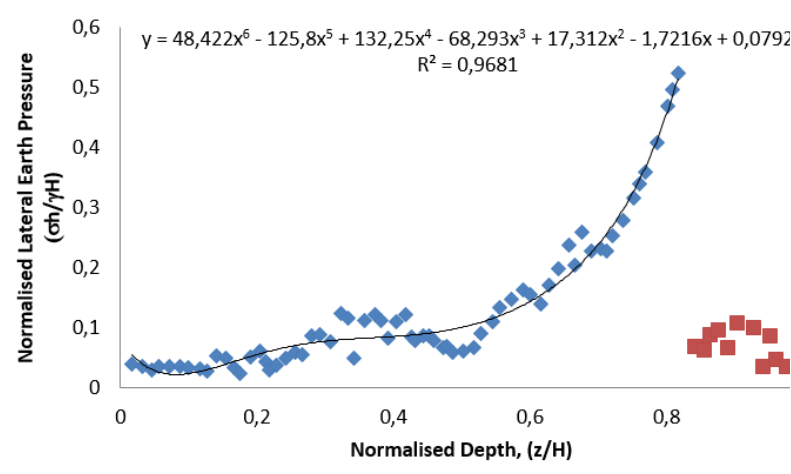

(a)

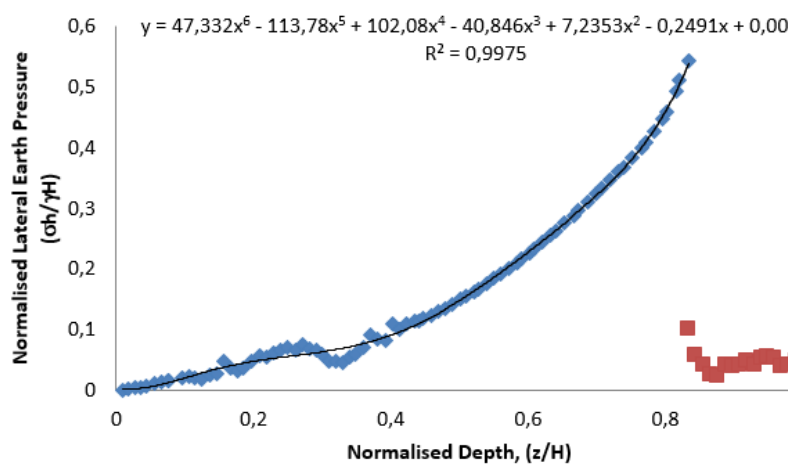

(b)

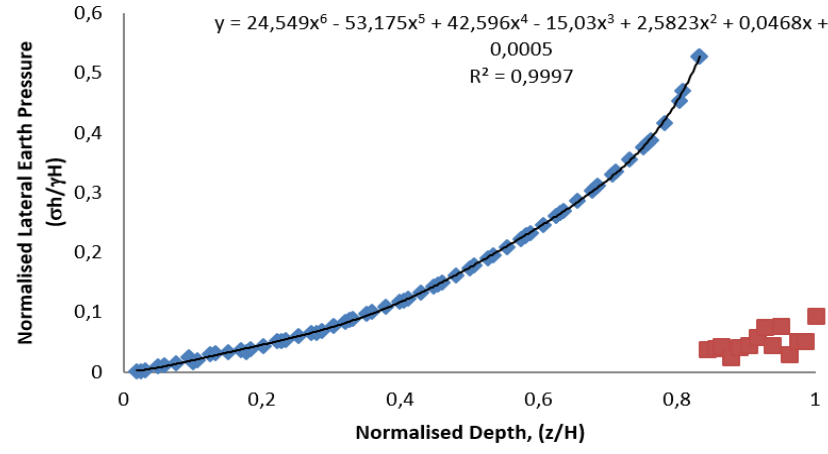

(c)

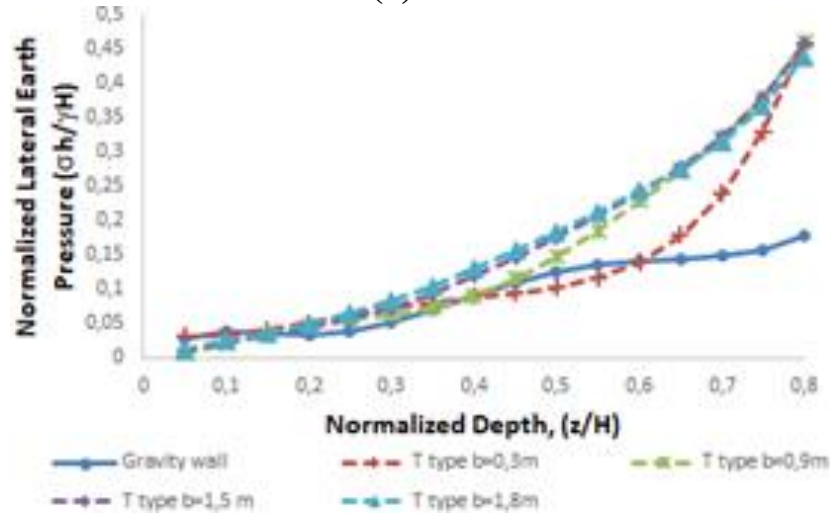

(d)

Figure 8. Active earth pressure distribution acting on the inverted $\mathrm{T}$ type retaining wall with different heel lengths (a) $b=0.3 \mathrm{~m}$ (b) $b=0.9 \mathrm{~m}$ (c) $b=1.5 \mathrm{~m}$ (d) Lateral earth pressure distribution acting on the inverted $\mathrm{T}$ type walls with various heel lengths (Kamiloglu et al. 2019)

In Figure 9 inverted $\mathrm{T}$ type cantilever retaining walls with different heel lengths $(b=$ $0.3 \mathrm{~m}$ and $b=1.5 \mathrm{~m})$ and inclination angles $\left(\theta=10^{\circ}\right.$ and $\left.\theta=20^{\circ}\right)$ are considered. Effect of the wall inclination on the lateral earth pressure distribution is shown in Figure 9.

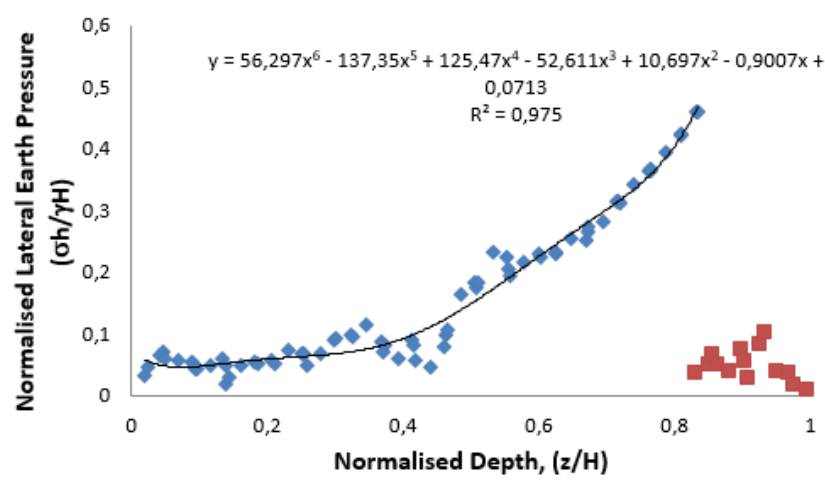

(a) 


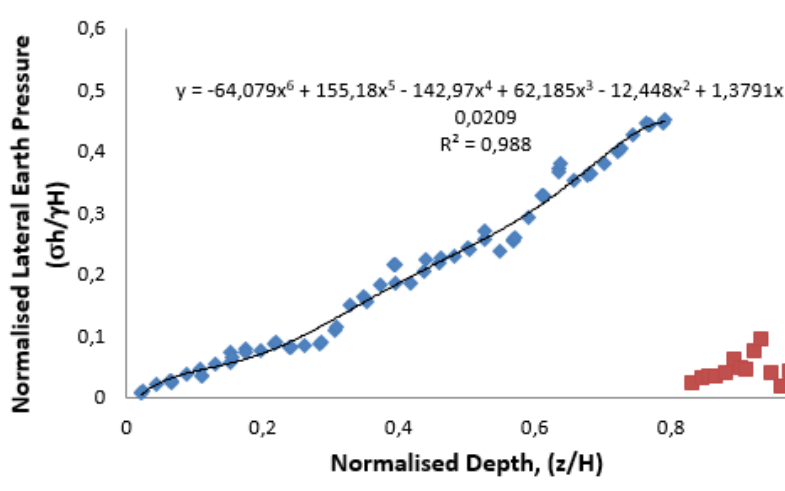

(b)

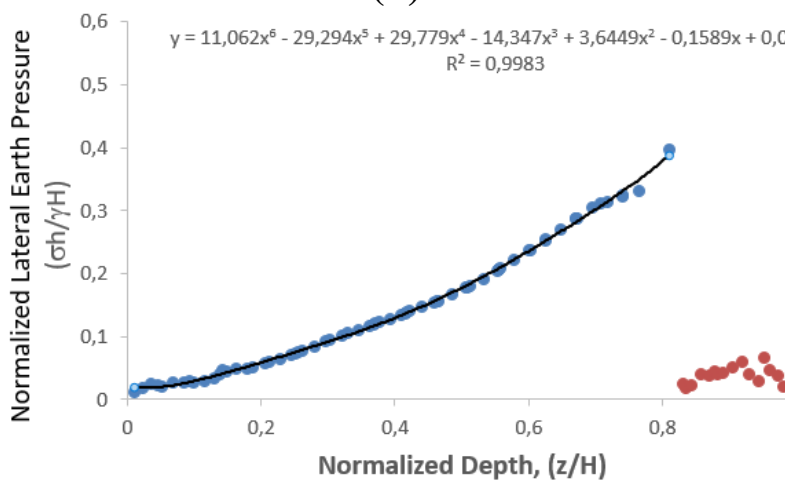

(c)

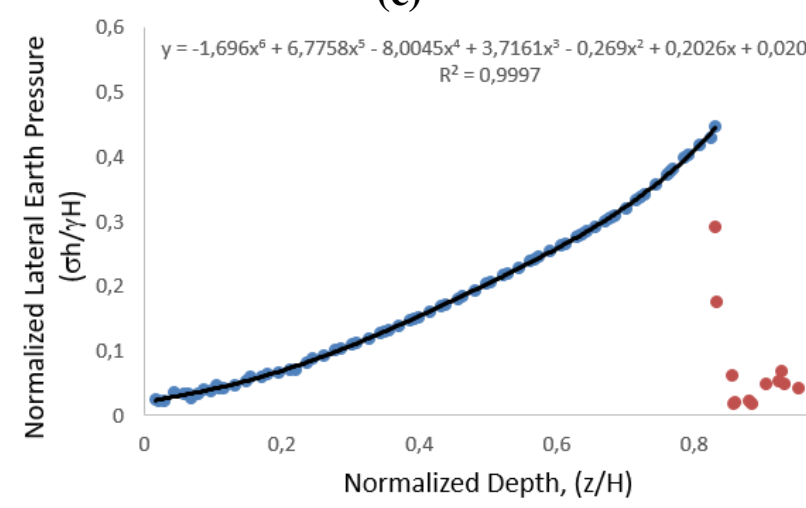

(d)

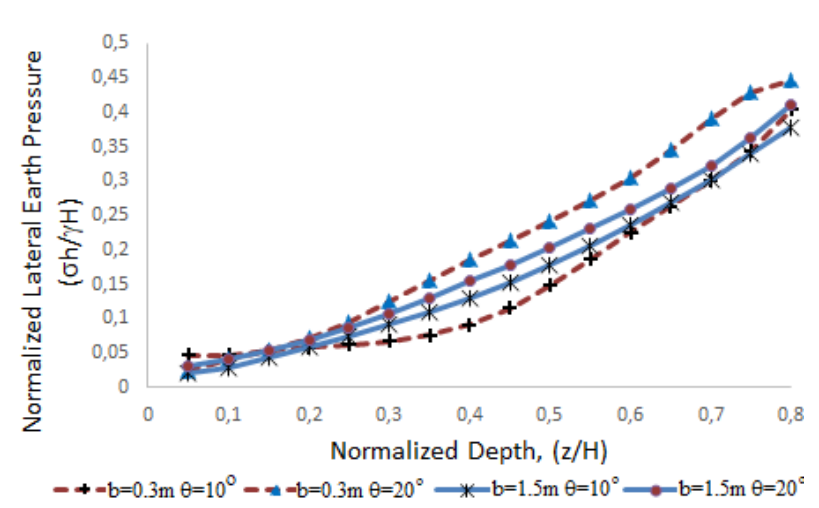

(e)

Figure 9. Active earth pressure distribution acting on the inverted $\mathrm{T}$ type retaining wall with different heel lengths and inclinations (a) $\mathrm{b}=0.3 \mathrm{~m}, \theta=10^{\circ}$ (b) $b=0.3 \mathrm{~m}, \theta=20^{\circ}$ (c) $b=1.5$ $\mathrm{m}, \theta=10^{\circ}$ (d) $\mathrm{b}=1.5 \mathrm{~m}, \theta=20^{\circ}$ (e) Lateral earth pressure distribution acting on the inverted $\mathrm{T}$ type walls with various heel lengths and inclinations.

\section{Results}

By viewing strain fields shown in Figure 4, Figure 5 and Figure 6 it is seen that wall type has considerable effects on failure surface mechanism. Heel of the retaining walls shown in Figure $4 b, 4 c, 6 a$ and $6 \mathrm{~b}$ can be classified as short heel and the walls shown in Figure $4 d, 6 c$ and $6 \mathrm{~d}$ can be classified as long heel considering the suggestions of various studies (R. V. Greco, 2014; V. R. Greco, 2001). Due to heel length, a triangular soil wedge occurs between the stem and the heel of $\mathrm{T}$ type cantilever retaining walls with short heel (Figure 4b, 4e, 6a and 6b). Dimension of the triangular mass increases with increasing heel length. On the other hand, polygonal soil mass occurs on the stem of the wall with long heel (Figure $6 \mathrm{c}$ and $6 \mathrm{~d}$ ). Due to the soil mass occurring above the heel, contact surface does not occur between the stem and the backfill.

The failure surfaces, friction between retaining wall and backfill are essential factors to constitute arching effect. By virtue of arching effect, lateral earth pressure distribution is different than suggestions of conventional theories (Coulomb, 1776; Rankine, 1857) (Figure 7). Additionally, from the Figure $7 \mathrm{f}$ it is seen that lateral earth pressure increased with increasing wall inclinations.

After examining Figure 4, Figure 5 and Figure 6 it is seen that gravity retaining wall has the largest friction area and the friction area reduces with increasing heel lengths. Correspondingly, due to the friction, less lateral earth pressure acts on gravity retaining wall compared to $\mathrm{T}$ type retaining walls 
(Figure 8a, 8b, 8c and 8d). On the other hand, lateral earth pressure acting on the stem of the inverted Type cantilever wall increases up to a certain heel length. In inverted $T$ type retaining walls increasing wall inclination leads to increase lateral earth pressure distribution due to the arching effect (Figure 8d). Because, friction surfaces between wall and backfill decreases with increasing wall inclination (Figure 6a and 6b).

The factors leading to increase lateral earth pressure are failure surface and reduced friction area. The soil block forms above the foundation due to the heel (Figure 5 and Figure 6). Thus, friction between wall and backfill does not occur. Increasing heel length leads to reduce friction area between the stem and backfill.

Active failure surface occurs above the heel of the inverted $\mathrm{T}$ type retaining walls. In active case, soil particles move along the failure surfaces. On the other hand, non-moving soil blocks with respect to moving adjacent soil blocks occur due to the heel. Shear stress occurs between the particles through the surface. Therefore, as it is shown in Figure 7, vertical earth pressure increases as it approaches to the failure surface. After examining Figure $8 \mathrm{a}, 8 \mathrm{~b}, 9 \mathrm{a}$ and $9 \mathrm{~b}$ it is seen that heel length is effective parameter for the walls with short heel. Lateral earth pressure acting on the stem increases with increasing heel length. Nonetheless, heel length has no effect on lateral earth pressure for the walls with long heel. As it is shown in Figure 8d, lateral earth pressure distribution becomes constant for the walls with long heel.

From the Figure 9e it is seen that wall inclination has considerable effect on lateral earth pressure distribution of the inverted $\mathrm{T}$ type retaining walls. In inverted $\mathrm{T}$ type of retaining walls increasing wall inclination leads to increase lateral earth pressure. Effect of inclination can be seen explicitly in the walls with short heel.

After examining Figure 8a, 8b, 8c, 9a, 9b and $9 \mathrm{c}$, it is seen that normalized lateral earth pressure acting on the foundation varies between 0.02 and 0.1 . The reason is that, active failure surface occurs very close to foundation. Due to the arching effect, far less lateral earth pressure acts on the foundation with respect to the stem. Furthermore, earth pressure acting on the foundation is not affected from heel length.

\section{Conclusions}

In the present study, effects of different wall dimensions on lateral earth pressure distribution are evaluated numerically using finite element method. Within this scope, gravity retaining walls and inverted $\mathrm{T}$ type cantilever retaining walls with $3 \mathrm{~m}$ height were considered. Heel length and wall inclination parameters were taken into account. Active failure mechanism and lateral earth pressure distribution acting on stem and foundation is investigated. Substantial findings of the study are summarized below;

- Contact surface and failure surfaces have prime importance on lateral earth pressure distribution.

- Lateral earth pressure distribution varies based on retaining wall type.

- Contact surfaces and failure surfaces are effective on lateral earth pressure distribution.

- Wall inclination has effect on failure mechanism and lateral earth pressure distribution. 
- As the case with heel length, wall inclination plays effective role in long heel or short heel cases.

- Short heel and long heel cases play decisive role in lateral earth pressure distribution. Heel length is effective parameter for the walls with short heel. On the other hand, heel length has no effect on lateral earth pressure for the walls with long heel.

\section{References}

Chen, W. F., \& Liu, X. L. 1990. "Limit Analysis in Soil Mechanics" , Amsterdam: Elsevier.

Chevalier, B., Combe, G., \& Villard, P. 2008. "Experimental and Numerical Studies of Load Transfers and Arching Effect",The $12^{\text {th }}$ International Conference of International Association for Computer Methods and Advances in Geomechanics (IACMAG). Goa, India.

Chugh, A. K., \& Labuz, J. . (2011). "Numerical Simulation of an Instrumented Cantilever Retaining Wall", Canadian Geotechnical Journal, 48(9), 1303-1313.

Çinicioğlu, Ö., Altunbaş, A., Soltanbeigi, B., \& Gezgin, A. T. 2015. "Characterization of Active Failure Wedge for Cohesionless Soils", Geotechnical Engineering for Infrastructure and Development: XVI European Conference on Soil Mechanics and Geotechnical Engineering. Edinburgh, Scotland.

Coulomb, C. A. 1776. "Essai sur une application des règles de maximis \& minimis à quelques problèmes de statique, relatifs à l'architecture" Des Sciences Memoires de MATh. et Physique Par Divers Savants, 7, 343-382.

Dewaikar, D. M., Pandey, S. R., \& Dixit, J. 2012. "Active Thrust on an Inclined Retaining Wall With Inclined Cohesionless Backfill Due to Surcharge Effect", ISRN Soil Science, https://doi.org/10.5402/2012/750386

Ertuğrul, N. A. 2013. "Effect of Soil Arching
On Lateral Soil Pressures Acting Upon Rigid Retaining Walls", MSc Thesis, The Graduate School of Natural and Applied Sciences Middle East Technical University.

Fang, Y. S., \& Ishibashi, I. 1986. "Static Earth Pressures With Various Wall Movements" Journal of Geotechnical Engineering, 112(3), 317-333.

Goh, A. T. C. 1993. "Behavior of Cantilever Retaining Walls", Journal of Geotechnical Engineering, 119(11), 1751-1770. https://doi.org/10.1061/(ASCE)07339410(1993)119:11(1751)

Greco, R. V. 2014. "Analytical Solution of Seismic Pseudo-Static Active Thrust Acting on Fascia Retaining Walls", Soil Dynamics and Earthquake Engineering, 57, 25-36.

Greco, V. 2013. "Active Thrust on Retaining Walls of Narrow Backfill Width" Computers and Geotechnics, 50, 66-78. https://doi.org/10.1016/j.compgeo.2012.12.0 07

Greco, V. R. 2001. "Active Earth Thrust on Cantilever Walls With Short Heel", Canadian Geotechnical Journal, 38(2), 401-409.

Handy, R. L. 1985. "The Arch in Soil Arching", Journal of Geotechnical Engineering ASCE, 111(3), 302-318.

Kamiloğlu, H. A., \& Şadoğlu, E. 2019. "Experimental and Theoretical Investigation of Short and Long Heel Cases of Cantilever RetainingWalls in Active State", International Journal of Geomechanics. https://doi.org/10.1061/(ASCE)GM.19435622.0001389

Kamiloğlu, H. A., Şadoğlu, E., \& Yılmaz, F. 2019. Numerical Analysis of Active Earth Pressures on Inverted $\mathrm{T}$ Type and SemiGravity Walls. 3rd International Conference on Advanced Engineering Technologies. Bayburt.

Le, X., Wu, Y., \& He, S. 2010. "Seismic Stability Analysis of Gravity Retaining Walls" Soil Dynamics and Earthquake Enginnering, 30, 875-878.

Lee, J. S., Chae, H. G., Kim, D. S., Jo, S. B., 
\& Park, H. J. 2015. "Numerical Analysis of Inverted T-type Wall Under Seismic Loading" Computers and Geotechnics, 66, 85-95. https://doi.org/10.1016/j.compgeo.2015.01.0 13

Leśniewska, D., \& Mróz, Z. 2000. "Limit Equilibrium Approach to Study The Evolution of Shear Band Systems in Soils" Géotechnique, 50(5), 521-536.

Liu, J., Sun, X., Sun, X., Wang, B., Liu, W., \& He, J. 2017. "Experimental Study of Active Earth Pressure on Rigid Retaining Walls with Narrow Backfill", 2016 International Conference on Mechanics and Materials Science (MMS2016), Guangzhou, China, 864-869.

Morisson, E. E., \& Ebeling, R. M. 1995. "Limit Equilibrium Computation of Dynamic Passive Earth-Pressure." Canadian Geotechnical Journal, 32, : 481-487.

Nadukuru, S. S., \& Michalowski, R. L. 2012. "Arching in Distribution of Active Load on Retaining Walls", Journal of Geotechnical and Geoenvironmental Engineering, 138(5), 575-584.

https://doi.org/10.1061/(Asce)Gt.1943-

5606.0000617

Paik, K. H., \& Salgado, R. 2003. "Estimation of Active Earth Pressure Against Rigid Retaining Walls Considering Arching Effects", Geotechnique, 57(7), 643-653. https://doi.org/10.1680/geot.53.7.643.37385

Rankine, W. J. M. 1857. "On the Stability of Loose Earth", Philosophical Transactions of the Royal Society of London (1776-1886). 1857-01-01. 147:9-27.

Shiau, J. S., Augarde, C. E., Lyamin, A. V., \& Sloan, S. W. 2009. "Finite Element Limit Analysis of Passive Earth Resistance in Cohesionless Soils" Soils and Foundations, 48(6),843-850.

https://doi.org/10.3208/sandf.48.843

Terzaghi, K. 1943. "Theoretical Soil Mechanics". New York: Wiley.

Tsagareli, Z. V. 1965. Experimental Investigation of the Pressure of a Loose
Medium on Retaining Walls With a Vertical Back Face And Horizontal Backfill Surface", J. Soil Mech. Found. Engng, ASCE, 91(4), 197-200.

Iskander, G.M. 2012. Simplified Analytical Solution for Point Load Acting Behind a Cantilever Wall", Advances International Journal for Numerical and Analytical Methods in Geomechanics, 36(3), 96-100.

Wang, Y. Z. 2000. Distribution of Earth Pressure on a Retaining Wall. Geotechnique, 50(1), 83-88.

Yang, X. L. 2007. "Upper Bound Limit Analysis of Active Earth Pressure with Different Fracture Surface and Nonlinear Yield Criterion", Theoretical and Applied Fracture Mechanics, 47(1), 46-56. 